\title{
Role of Tyro3, Axl, and Mer Receptors and Their Ligands (Gas6, and Protein S) in Patients with Hepatocellular Carcinoma
}

\author{
Soichiro Uehara*, Yuichi Fukuzawa, Tomohiko Matuyama, Katuhiro Gotoh \\ Department of Gastroenterology, Hizirigaoka Hospital, Date, Japan \\ Email: *ootaki_ph@ jikeikai.or.jp
}

How to cite this paper: Uehara, S., Fukuzawa, Y., Matuyama, T. and Gotoh, K. (2017) Role of Tyro3, Axl, and Mer Receptors and Their Ligands (Gas6, and Protein S) in Patients with Hepatocellular Carcinoma. Journal of Cancer Therapy, 8, 112130.

https://doi.org/10.4236/jct.2017.82010

Received: December 26, 2016

Accepted: February 6, 2017

Published: February 9, 2017

Copyright $\odot 2017$ by authors and Scientific Research Publishing Inc. This work is licensed under the Creative Commons Attribution International License (CC BY 4.0).

http://creativecommons.org/licenses/by/4.0/

\begin{abstract}
The Tyro3, Axl and Mer (TAM) receptor tyrosine kinases are activated by endogenous ligands, protein S1 (PROS1) and growth arrest-specific gene 6 (Gas6), and those have important effects on cell biology. These receptors (Rs) can be shad from the cell membrane and their soluble(s) forms can be found in plasma. We investigated the fluctuation and interactive role of sTAMRs and its ligands in patients with hepatocellular carcinoma (HCC), hepatitis groups, and healthy normal adult controls (NC). The measurement cases were 45 patients with HCC group (stage 1 in 4, stage 2 in 8 , stage 3 in 16, and stage 4 in 17), 4 patients with fulminant hepatitis (FH), 14 patients with acute hepatitis $(\mathrm{AH}), 10$ patients with chronic hepatitis $(\mathrm{CH}), 16$ patients with liver cirrhosis (LC), and 20 NCs matched by age. Plasma levels of three sTAMRs and their ligands were measured by ELISA. In comparison with NCs, Gas6, des$\gamma$-carboxy Gas6, and sTAMRs levels were significantly higher in HCC patients, but free PROS1 levels were significantly lower. The sTyro3 and sAxl levels peaked HCC stages 2 and 3 respectively, and gradually decreased afterwards while maintaining high levels. sMer levels increased with the progression of HCC. Gas6 and des- $\gamma$-carboxy Gas6 levels gradually increased, and PROS1 levels decreased with the progression of HCC. Gas6 levels were positively correlated with sAxl levels, whereas sMer levels were negatively correlated with free PROS1 levels. sTAMRs and Gas6 levels increased in parallel to the progression of HCC fibrosis. Through the progression of HCC, Axl played the major role in TAMRs activation. However, sTYro3 continued increasing rapidly from the early stage, and that of Mer increased throughout the progression. Roles of Axl may be changed in Mer, because des- $\gamma$-carboxy Gas6 levels increasing with Gas6 in the advanced stage of HCC cannot send a signal to Axl.
\end{abstract}

\section{Keywords}

Tyro3, Axl, Mer, Gas6, Protein S, Hepatocellular Carcinoma 


\section{Introduction}

The TAM receptor tyrosine kinases comprised of Tyro3, Axl and Mer, have been under intense study over the last several years for their involvement in the resolution of inflammation, autoimmunity, and most recently for their role in cancer progression and tumor immunology.

The $\mathrm{Tyro3}^{-/-}$mice develop neurological disorders. $\mathrm{Axl}^{-/-}$mice have vascular defects (like $\mathrm{PROS1}^{-/-}$and $\mathrm{Gas}^{-1-}$ ) impaired vascular remodeling after hemodynamic stress and an increased inflammatory response in central nervous system, caused by reduced debris removal. $\mathrm{Mer}^{--}$mice show many autoimmune like features.

Deficiencies in the expression or activities of Tyro3, Axl, and Mer (TAM) lead to autoimmunity, blindness, and infertility. Conversely, TAM receptors (TAMRs) are overexpressed in a variety of cancers and possess a gain of function ability to activate oncogenic and survival signaling pathways. In many of these cancers, the level of overexpression positively correlates with chemo-resistance, metastasis, and poor survival outcome [1] [2] [3].

TAMRs can be activated by their ligands of the vitamin K-dependent protein growth arrest-specific gene 6 (Gas6) and Protein S1 (PROS1). PROS1 is produced by a various cell types, such as hepatocytes, endothelial cells, megakaryocytes, and osteoblasts and is most commonly known as an important co-factor for protein C, as well as a direct inhibitor of multiple coagulation factors [1] [2] [3].

Gas6 and PROS1 bind to phosphatidylserine-positive moieties with their Nterminal $\gamma$-carboxylated glutamic acid (Gla)-domain. The C-terminal domain binds to Mer on macrophages, Axl and Tyro3 on dendritic cells, and enveloped viruses, triggering phosphorylation by the intracellular kinase domain. It is indispensable for the bioactivity of the Gla domain-containing proteins of the coagulation cascade and is a principal reason that vitamin $\mathrm{K}$ is an essential vita$\min [4][5]$.

Gas6 Gla domain is required for optimal activation of Tyro3 and Mer, and that this requirement is absolute for Axl [4] [5]. Gas6 and PROS1 share 44\% amino acid sequence identity and have the same domain structure with the exception of thrombin cleavage sites which are present in PROS1 but not in Gas6.

In contrast to the vitamin $\mathrm{K}$-dependent proteins of blood coagulation cascade, Gas6 is not primarily synthesized in the liver, but it is expressed in diverse sites, such as the lungs, heart, kidney, intestine, ovary, testis, brain, bone marrow, and vascular endothelium with a plasma concentration approximately 1000-fold lower than that of PROS1. Approximately 40\% PROS1 circulates as free PROS1 and $60 \%$ as a complex with C4 binding protein (C4BP) [3] [4] [5]. Only free PROS1 is active as a cofactor for activated protein $\mathrm{C}$ and ligand for the TAMRs kinases. In the absence of free PROS1, there is an increased risk of thromboembolism.

Gas6 is a common ligand for all three TAMRs with different affinities (Axl > Tyro3 > Mer), whereas PROS1 activates Tyro3 and Mer (Tyro3 > Mer), but not Axl. Gas6 binds with high affinity to Axl, with a Kd (dissociation constant) in 
the subnanomolar range, whereas its affinities for Tyro3 and Mer are slightly lower [4] [5].

Current knowledge indicates that tubby-like protein 1 (tulp1) can bind and signal through TAMs, whereas tubby signals only through Mer [4] [5].

Membrane-bound TAMs generate soluble ligands-binding domains by proteolytic cleavage of the extracellular domain to yield a secreted protein, and these soluble types are measured in blood.

Both the Axl and Mer receptors are susceptible to posttranslational regulation via ectodomain shedding mediated by a disintegrin and metalloprotease domain (-ADAM-) metallopeptidases, and Mer is resolved by ADAM17 [6] [7]. Mouse Axl is cleaved by ADAM10, but the cleavage of human Axl is unclear. There is no report about Tyro3. The surface proteins of natural killer (NK) cells and CD44, which stem cell of hepatocellular carcinoma (HCC), are cleaved by ADAM10. sMer and sCD163 are generated by shedding and are variable biomarkers of $\mathrm{M}_{2} \mathrm{c}$ macrophage activation. In general, M2 macrophages damp inflammation and promote tissue remodeling and tumor progression [6] [7].

These soluble fragments have been shown to interact with ligands, modifying their functions for the Gas6/PROS1-TAM system as well as serving as markers of its state of activation [3].

An increase in Axl levels in HCC has been reported [8]. Activation of Axl signaling by its ligand Gas6 leads to enhanced proliferation, survival, invasion, and metastasis of cancer cells. In HCC, in situ hybridization revealed the up-regulation of Axl and a further study suggested that Axl acts downstream of the Hippo pathway to trigger cell invasion and metastasis [9].

In a study of sAxl in many patients with very early-stage HCC, serum levels of sAxl were significantly increased in HCC patients in comparison with healthy or cirrhotic controls [10]. In addition, there are many reports on an increase in sAxl levels in HCC. There is a report of overexpression of Tyro3 through the progression of HCC [11].

The role of TAMRs in liver inflammation has been studied. Many of these studies mention the protection of the liver by Gas6.

The mechanisms by which ligands activate TAMRs are not well understood. There are few clinical studies in contrast to the number of in vitro studies in this area.

In this present study, we investigated the interaction and role of three TAMRs and their ligands in HCC by measuring three soluble TAMRs and their ligands in HCC, other liver disease (i.e. fulminant hepatitis (FH), acute hepatitis (AH), chronic hepatitis (CH), liver cirrhosis (LC)), and normal healthy subjects (NCs) for control groups.

\section{Methods}

\subsection{Study Population}

Our study was approved by the ethics committee of Hijirigaoka Hospital which complies with the Treaty of Helsinki. A total of 99 patients were included in this 
study. All patients gave informed consent and all agreed to donate blood samples and clinical information for the study. Control samples were collected from 20 healthy staff members in our hospitals.

\subsection{Patients}

The study group comprised 45 patients with HCC and 20 adult normal controls (NCs) matched by age. Four cases of FH, 14 cases of $\mathrm{AH}, 10$ cases of $\mathrm{CH}$, and 16 cases of LC were also studied. The details of these patients are shown in Table 1.

\subsection{Patients Backgrounds}

HCC was diagnosed by abdominal ultrasonography, abdominal computed tomography (CT), magnetic resonance imaging (MRI), abdominal angiography, and elevated serum concentrations of $\alpha$-fetoprotein and des $\gamma$-caeboxyprothrombin (PIVKA-2).

The pathological tumor node metastasis (TNM) stages of HCC according to the Liver Cancer Study Group of Japan [12] [13] were stage 1 in 4 , stage 2 in 8 , stage 3 in 16, and stage 4 in 17 patients.

Three types of nodular, diffuse and massive of macroscopic morphological stratification of HCC are based on the classification of Enggel [14] by using EC and CT. The number of three form types cases of nodular (cancer nodes lies scattered), diffuse, (It is occupied by innumerable hepatic cirrhosis-like carcinoma nodes), and Massive (It is occupied by giant carcinoma nodes) were 17, 14, and 14 respectively. Child-Pugh classification score for these liver diseases were also calculated.

The number of cases receiving Child-Pugh A, B, and C scores for $\mathrm{HCC}$ were 3 , 21 , and 21 respectively [15].

The 14 cases of AH were all positive for human hepatitis A (HVA) antibody and cured within 8 weeks. The diagnosis of $\mathrm{FH}$ was performed as described by Fujiwara et al. [16]. All 4 FH patients fell into hepatic coma within 1 - 2 weeks of onset, and plasmapheresis treatment was performed in all cases, but all patients died with 14 - 21 hospital days. The diagnosis of chronic hepatitis and LC was based on clinical and biochemical evidence, and confirmed by liver biopsy, EC, and CT.

The Child-Pugh classifications of these patients are shown in Table 1.

Venous blood samples were obtained on patients' admission. Plasma samples were collected in citric acid (3.8\%) and ethylenediaminnetetraacetic acid, and frozen immediately for storage at $-60^{\circ} \mathrm{C}$ until analysis.

Serum alanine transaminase (ALT), aspirate transaminase (AST), and bilirubin levels, and white blood cell and platelet counts were measured using routine laboratory procedures, and laboratory screening included testing for human hepatitis A virus antigen (HAV), hunman hepatiis B virus antigen (HVB), human hepatitis $\mathrm{C}$ virus antigen (HCV). The blood levels of the liver (ALT and AST), functioning of the kidney (blood ureanitrogen, and creatine), cholesterol, and blood corpuscles for the NCs were all within normal ranges. 
Table 1. Clinical characteristics of the patients Data are mean \pm standard deviation.

\begin{tabular}{|c|c|c|c|c|c|c|c|c|c|}
\hline & $\begin{array}{l}\text { Normal } \\
\text { controls }\end{array}$ & $\begin{array}{c}\text { HCC-Stage } \\
\text { I }\end{array}$ & $\begin{array}{c}\text { HCC-Stage } \\
\text { II }\end{array}$ & $\begin{array}{c}\text { HCC-Stage } \\
\text { III }\end{array}$ & $\begin{array}{c}\text { HCC-Stage } \\
\text { IV }\end{array}$ & $\mathrm{FH}$ & $\mathrm{AH}$ & $\mathrm{CH}$ & LC \\
\hline $\begin{array}{l}\text { Number } \\
\text { of cases }\end{array}$ & 20 & 4 & 8 & 16 & 17 & 4 & 14 & 10 & 16 \\
\hline Age (years) & $57.8 \pm 18.5$ & $66.8 \pm 14.6$ & $60 \pm 7.7$ & $56.1 \pm 7.6$ & $58.2 \pm 15.1$ & $45.8 \pm 20.8$ & $31.2 \pm 4.2$ & $58.9 \pm 8.3$ & $63.0 \pm 11.6$ \\
\hline $\begin{array}{c}\text { Gender } \\
\text { (female; male) }\end{array}$ & $10 ; 10$ & $2 ; 2$ & $2 ; 6$ & $4 ; 12$ & $6 ; 10$ & $2 ; 2$ & $5 ; 9$ & $7 ; 3$ & $9 ; 8$ \\
\hline $\begin{array}{c}\text { Etiology } \\
\text { (A:B:C:none) }\end{array}$ & 0:0:0:0 & 0:1:3:0 & $0: 2: 6: 0$ & 0:6:10:0 & $0: 12: 6: 0$ & $0: 2: 2: 0$ & 14:0:0:0 & 0:0:4:6 & 0:6:9:1 \\
\hline $\begin{array}{l}\text { Child-Pugh } \\
\text { grade } \\
(\mathrm{A} ; \mathrm{B} ; \mathrm{C})\end{array}$ & $0 ; 0 ; 0$ & $0 ; 1 ; 3$ & $0 ; 6 ; 2$ & $0 ; 8 ; 8$ & $0 ; 3 ; 14$ & $0 ; 0 ; 4$ & $14 ; 0 ; 0$ & $0 ; 10 ; 0$ & $1 ; 12 ; 3$ \\
\hline $\begin{array}{l}\text { Albumin } \\
(\mathrm{g} / \mathrm{dl})\end{array}$ & $3.3 \pm 0.2$ & $2.9 \pm 0.4$ & $2.8 \pm 0.5$ & $2.5 \pm 1.3$ & $2.3 \pm 0.3$ & $3.0 \pm 0.4$ & $2.7 \pm 0.7$ & $2.8 \pm 0.6$ & $2.3 \pm 0.5$ \\
\hline $\begin{array}{l}\text { Platelet } \\
\left(10^{4} / \mu \mathrm{l}\right)\end{array}$ & $25.6 \pm 0.8$ & $15.0 \pm 0.4$ & $13.6 \pm 28$ & $10.8 \pm 3.6$ & $10.4 \pm 1.3$ & $7.6 \pm 0.8$ & $21.8 \pm 1.5$ & $18.3 \pm 1.2$ & $9.7 \pm 1.2$ \\
\hline $\begin{array}{c}\text { ALT } \\
(\mathrm{IU} / \mathrm{l})\end{array}$ & $24.1 \pm 0.5$ & $54.5 \pm 22.4$ & $218.6 \pm 124.3$ & $285.4 \pm 213.8$ & $304.7 \pm 231.8$ & $643.4 \pm 321.5$ & $356.8 \pm 445.8$ & $98.5 \pm 56.4$ & $110.4 \pm 85.6$ \\
\hline $\begin{array}{l}\text { AST } \\
(\mathrm{IU} / \mathrm{l})\end{array}$ & $35.4 \pm 13.5$ & $68.8 \pm 45.6$ & $358.8 \pm 239.4$ & $374.6 \pm 278.1$ & $335.9 \pm 245.4$ & $768.2 \pm 459.7$ & $453.7 \pm 334.8$ & $178.5 \pm 99.7$ & $143.5 \pm 64.3$ \\
\hline $\begin{array}{c}\mathrm{AFP} \\
(\mathrm{ng} / \mathrm{ml})\end{array}$ & $15.4 \pm 18.5$ & $45.2 \pm 14.6$ & $326.7 \pm 116.8$ & $1589.6 \pm 2486.3$ & $3281.5 \pm 3221.4$ & $68.9 \pm 20.8$ & $28.4 \pm 25.3$ & $43.8 \pm 19.8$ & $44.8 \pm 32.6$ \\
\hline $\begin{array}{c}\text { DCP } \\
(\mathrm{mAu} / \mathrm{ml})\end{array}$ & $12.7 \pm 10.6$ & $56.8 \pm 14.6$ & $445.9 \pm 112.6$ & $1894.2 \pm 778.5$ & $2412.7 \pm 2117.9$ & $43.1 \pm 30.4$ & $34.8 \pm 14.2$ & $56.3 \pm 21.5$ & $73.0 \pm 21.6$ \\
\hline
\end{tabular}

\subsection{Determination of sTAMRs Levels in Plasma}

Measurements of sTAMs were performed using commercial enzyme-linked immunesorbent assay (ELISA) kits using the sandwich technique.

For Tyro3, the sandwich ELISA kit used was DuoSet ${ }^{\circledR}$ (R\&D Systems, Minneapolis, MN, USA). Maxisorp (NUNC A/S, Roskilde, Denmark) plates were coated with the hTyro 3 monoclonal antibody. Plates were washed 5 times with phosphate-buffered saline (PBS: $\mathrm{pH}$ 7.3) between steps. Plasma samples were diluted 10 times with blocking buffer and applied to the plates.

A standard curve was constructed from serial dilutions of recombinant protein and negative controls were buffer alone. Biotinylated anti-hTyro3 antibody was used for detection together with hTyro3-1 $1^{\text {st }}$-antibody complex/horseradish peroxidase complexes according to the manufacturer's instructions. The plates were developed with orthophenylenediamine and hydrogen peroxide and the color reaction was stopped by the addition of $100 \mathrm{ul}$ of $1 \mathrm{M}$ sulfuric acid. The absorbance was determined in an automated plate reader at $490 \mathrm{~nm}$.

Plasma sAxl and sMer levels were determined using Human soluble AXL ELISA KIT (Aviscera Bioscience, Inc. Santa Clara, USA), and MERRTK ELISA Kit ( Abnova, Taipei, Taiwan) respectively.

\subsection{Determination of Gas6, Des- $\gamma$-carboxy Gas6, and Free PROS1 Levels in Plasma}

Gas6 and free PROS1 levels were determined using commercial ELISA kits that use the sandwich HUMAN GAS6 ELISA kit (Aviscera Bioscience, Inc. Santa 
Clara, USA) for Gas6 and des- $\gamma$-carboxy Gas6, and protein S test Teijin ${ }^{\mathrm{R}}$ (Teijin Diagnostics, Osaka, Japan) for free PROS1. Des- $\gamma$-carboxy Gas6 plasma sampling was performed by mixing the same volume of $1 \mathrm{M} \mathrm{BaCl}_{2}$ for $1 \mathrm{~h}$ at $37^{\circ} \mathrm{C}$, and centrifuged $2500 \mathrm{~g}$ for $10 \mathrm{~min}$. at $4^{\circ} \mathrm{C}$.

These intra- and inter-assay coefficients of variation for sAxl, sMer, sTyro3, Gas6, and fPROS1 were $8.3 \%$ and $9.2 \%, 9.8 \%$ and $12.4 \%, 3.5 \%$ and $4.0 \%, 11.0 \%$ and $7.1 \%$, and $7.4 \%$ and $8.4 \%$ respectively.

\subsection{Child-Pugh Scores}

The clinical status of cases was expressed as Child-Pugh scores.

\subsection{Statistical Analysis}

Data are expressed as mean \pm standard deviation. Statistical analysis was performed using Student's $t$-test and the level-of significance was set as $P<0.05$.

\section{Results}

\subsection{Plasma Levels of sTAMRs in Patients with HCC, FH, AH, CH, LC, and in NCs}

\subsubsection{Tyro3}

Significant increases in sTyro3 levels in patients with stage I - IV HCC, AH, $\mathrm{FH}$, and LC compared with NCs were observed $(1.75 \pm 0.66 \mathrm{ng} / \mathrm{ml}$ vs. $2.63 \pm$ $0.97^{\star *} \mathrm{ng} / \mathrm{ml}, 8.21 \pm 3.19^{* *} \mathrm{ng} / \mathrm{ml}, 6.11 \pm 2.33^{* *} \mathrm{ng} / \mathrm{ml}, 6.90 \pm 2.57^{* *} \mathrm{ng} / \mathrm{ml}, 6.55$ $\pm 2.87^{* *} \mathrm{ng} / \mathrm{ml}, 5.46 \pm 2.17^{* *} \mathrm{ng} / \mathrm{ml}$, and $\left.5.33 \pm 1.90^{* *} \mathrm{ng} / \mathrm{ml} ; P<0.01\right)$, but no differences were noted between patients with $\mathrm{CH}$ and NCs $(1.75 \pm 0.66 \mathrm{ng} / \mathrm{ml}$ vs. $1.72 \pm 0.64 \mathrm{ng} / \mathrm{ml}$ ) (Figure 1(a)).

A significant increase pertaining to the sTyro3 levels was noted between HCC stage II and III $\left(8.21 \pm 3.19^{* *} \mathrm{ng} / \mathrm{ml}\right.$ vs. $\left.2.63 \pm 0.97 \mathrm{ng} / \mathrm{ml}{ }^{* *} P<0.01\right)$, and the sTyro3 levels of HCC showed a peak in HCC stage $I$, and continued at a high level afterwards (Figure 1(a)).

\subsubsection{Axl}

Significant increases in sAxl levels in patients with stage III, IV HCC, AH, FH, and LC compared with NCs were observed $\left(26.9 \pm 3.0 \mathrm{ng} / \mathrm{ml}\right.$ vs. $72.3 \pm 20.8^{* *}$ $\mathrm{ng} / \mathrm{ml}, 69.5 \pm 25.2^{* *} \mathrm{ng} / \mathrm{ml}, 72.6 \pm 14.6^{* *} \mathrm{ng} / \mathrm{ml}, 43.6 \pm 11.9^{* *} \mathrm{ng} / \mathrm{ml} ; P<0.01$ and $\left.43.5 \pm 23.8^{\star} \mathrm{ng} / \mathrm{ml} ; P<0.05\right)$, but no differences were noted between patients with $\mathrm{CH}$ and $\mathrm{NCs}(25.9 \pm 3.0 \mathrm{ng} / \mathrm{ml}$ vs. $23.6 \pm 11.5 \mathrm{ng} / \mathrm{ml})$. The sAxl levels at HCC stage IV slightly decreased in comparison with those at HCC stage III $(72.3 \pm 20.8 \mathrm{ng} / \mathrm{ml}$ vs. $69.5 \pm 25.2 \mathrm{ng} / \mathrm{ml}$ ) (Figure $1(\mathrm{~b})$ ).

\subsubsection{Mer}

Significant increases in the sMer levels compared with NC were observed in patients with HCC stages $\mathbb{I I}$ and IV, III and IV, FH, and AH $(15.7 \pm 3.1 \mathrm{ng} / \mathrm{ml}$ vs. $23.2 \pm 9.3 \mathrm{ng} / \mathrm{ml}^{\star}, 24.2 \pm 7.3 \mathrm{ng} / \mathrm{ml}^{* *}, 72.7 \pm 36.2 \mathrm{ng} / \mathrm{ml}^{* *}, 30.9 \pm 19.6 \mathrm{ng} / \mathrm{ml}^{* *}$, $\left.{ }^{\star} P<0.05,{ }^{* *} P<0.01\right)$.

The sMer levels at each HCC stage increased with the development of the 
stage of the disease $(15.1 \pm 2.4,19.9 \pm 7.0,23.2 \pm 9.3$, and $24.2 \pm 7.3 \mathrm{ng} / \mathrm{ml})$.

For sMer, no significant differences were noted between patients with $\mathrm{CH}$, and $\mathrm{LC}$ and $\mathrm{NC}(13.2 \pm 3.4 \mathrm{ng} / \mathrm{ml}, 18.4 \pm 4.9 \mathrm{ng} / \mathrm{ml}$ vs. $15.7 \pm 3.1 \mathrm{ng} / \mathrm{ml})$ (Figure $1(\mathrm{c})$ ).

\subsection{Plasma Levels of Ligands (Gas6 and Free PROS1) in Patients with HCC, FH, AH, CH, and LC, and NCs}

\subsubsection{Gas6}

Plasma levels of Gas6 were higher in all HCC stages ( I - IV) than NCs $(18.2 \pm$ $2.6 \mathrm{ng} / \mathrm{ml}$ vs. $26.5 \pm 2.5^{\star \star} \mathrm{ng} / \mathrm{ml}, 33.3 \pm 7.1^{\star *} \mathrm{ng} / \mathrm{ml}, 73.7 \pm 26.7^{\star *} \mathrm{ng} / \mathrm{ml}, 81.6 \pm$ $34.3^{\star *} \mathrm{ng} / \mathrm{ml},{ }^{* *} P<0.01$ ) (Figure $2(\mathrm{a})$ ).

(a)

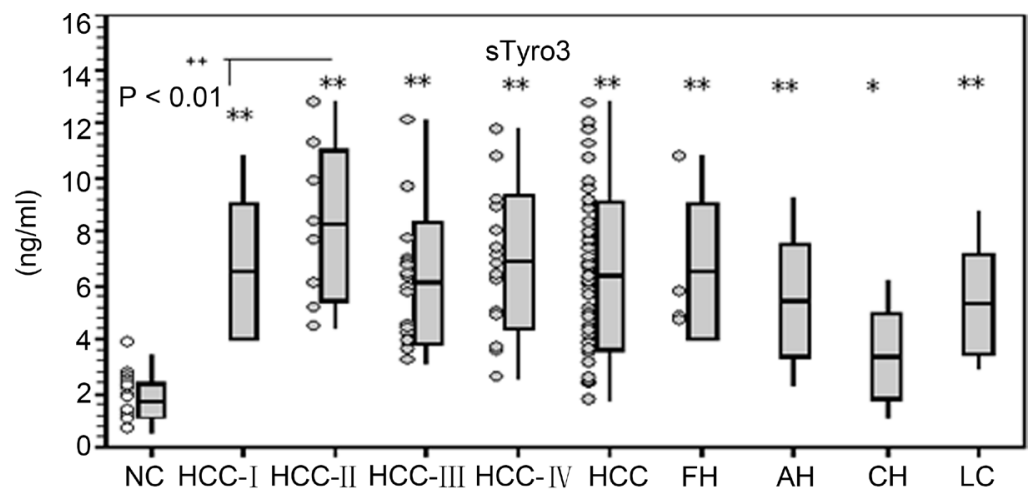

(b)

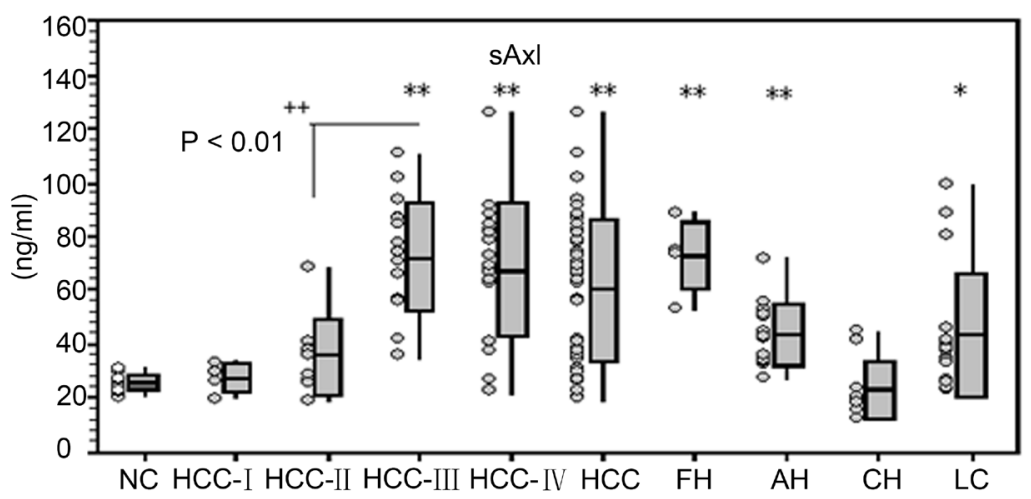

(c)

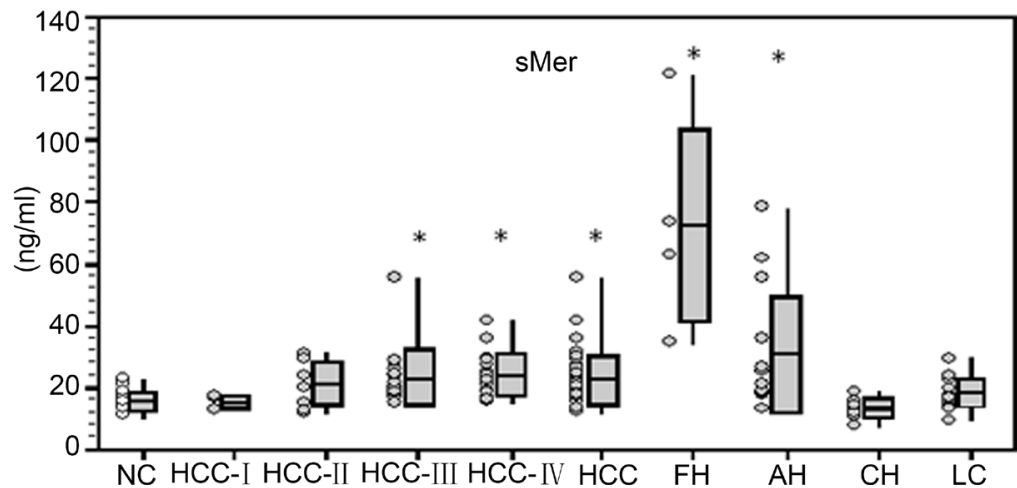

Figure 1. Plasma levels of sTyro3, sAxl, and sMer in patients with $\mathrm{HCC}, \mathrm{FH}, \mathrm{AH}, \mathrm{CH}$, and LC, and in normal controls. Data are mean $\pm \mathrm{SD}{ }^{\star} P<0.05,{ }^{\star *} P<0.01$ vs. NC, $+P<$ $0.05,++P<0.01$ vs. each stage of HCC. 
From stages I to III of HCC, Gas6 levels significantly increased, but the increase from stages III to $\mathrm{IV}$ of HCC were not significant $(26.5 \pm 2.5 \mathrm{ng} / \mathrm{ml}$ vs. $33.3 \pm 7.1^{\star} \mathrm{ng} / \mathrm{ml},{ }^{\star} \mathrm{P}<0.05 .33 .3 \pm 7.1 \mathrm{ng} / \mathrm{ml}$ vs $73.7 \pm 26.7^{* \star} \mathrm{ng} / \mathrm{ml},{ }^{\star \star} \mathrm{P}<0.01$. $73.7 \pm 26.7 \mathrm{ng} / \mathrm{ml}$ vs $81.6 \pm 34.3 \mathrm{ng} / \mathrm{ml})$.

The GAs6 levels in patients with $\mathrm{FH}, \mathrm{AH}$, and $\mathrm{CH}$ were decreased in comparison with those in NCs, but Gas6 levels in patients with LC were increased in comparison with those of NCs $\left(18.2 \pm 2.6 \mathrm{ng} / \mathrm{ml}\right.$ vs. $11.0 \pm 2.2^{* *} \mathrm{ng} / \mathrm{ml}, 15.7 \pm$ $5.1 \mathrm{ng} / \mathrm{ml}, 13.2 \pm 5.1^{\star} \mathrm{ng} / \mathrm{ml} ;{ }^{*} P<0.01,{ }^{\star} P<0.05$, vs. $28.6 \pm 17.2^{\star} \mathrm{ng} / \mathrm{ml} ;{ }^{*} P<$ 0.05) (Figure 2(a)).

\subsubsection{Free PROS1}

Plasma levels of free PROS1were lower in all ( I - IV) HCC stages in comparison with those in NCs $\left(11.0 \pm 1.2 \mathrm{ng} / \mathrm{ml}\right.$ vs. $8.2 \pm 1.7^{\star} \mathrm{ng} / \mathrm{ml}, 6.1 \pm 1.9^{* *} \mathrm{ng} / \mathrm{ml}$, $5.9 \pm 1.5^{\star \star} \mathrm{ng} / \mathrm{ml}, 5.9 \pm 1.5^{\star \star} \mathrm{ng} / \mathrm{ml} ;{ }^{\star} P<0.05,{ }^{* *} P<0.01$ ) (Figure $2(\mathrm{~b})$ ).

Free PROS1 levels in patients with $\mathrm{FH}, \mathrm{AH}$, and $\mathrm{CH}$ were decreased than $\mathrm{NC}$, but free PROA1 levels in patients with LC were increased than NC $(11.0 \pm 1.2$ $\mathrm{ng} / \mathrm{ml}$ vs $3.9 \pm 0.4^{* \star} \mathrm{ng} / \mathrm{ml}, 5.5 \pm 1.9^{* *} \mathrm{ng} / \mathrm{ml}, 7.8 \pm 1.5^{\star} \mathrm{ng} / \mathrm{ml} ;{ }^{*} \mathrm{P}<0.01,{ }^{*} \mathrm{P}<$ 0.05 , vs $5.7 \pm 1.7^{\star} \mathrm{ng} / \mathrm{ml} ;{ }^{\star} P<0.05$ ) (Figure $2(\mathrm{~b})$ ).

(a)

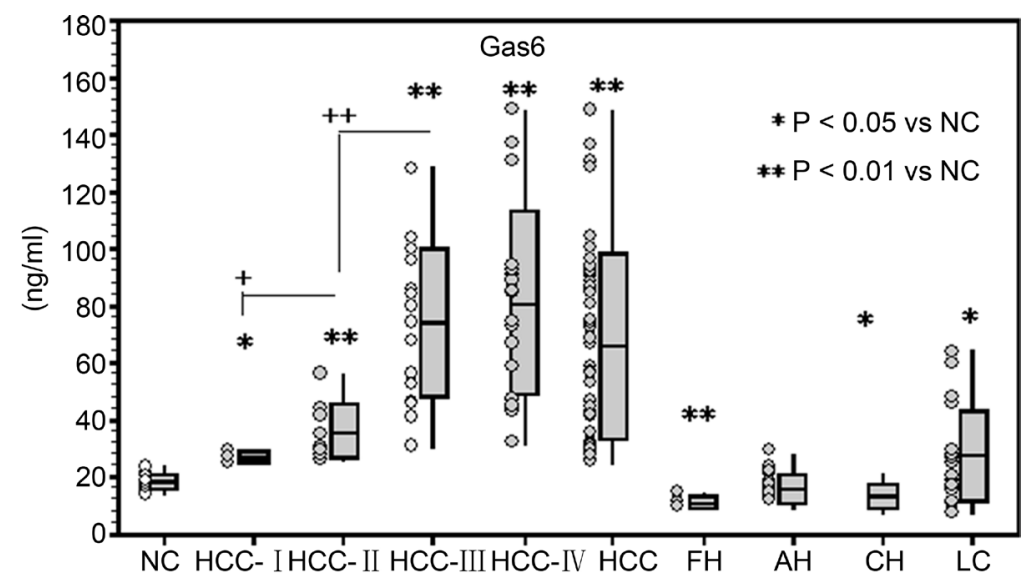

(b)

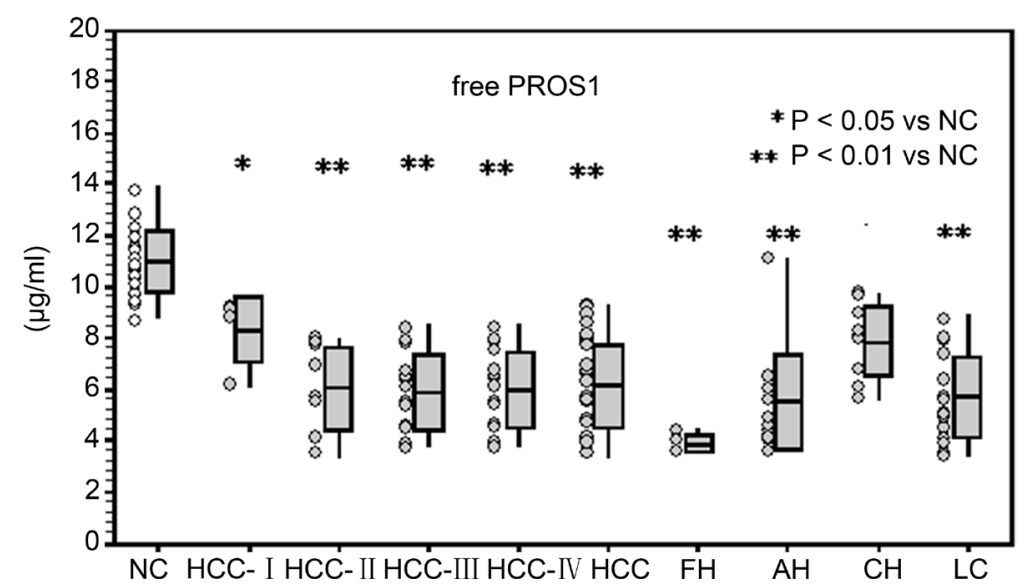

Figure 2. Plasma levels of Gas6, and free PROS1 in patients with $\mathrm{HCC}, \mathrm{FH}, \mathrm{AH}, \mathrm{CH}$, and $\mathrm{LC}$, and in normal controls. Data are mean $\pm \mathrm{SD}{ }^{\star} P<0.05,{ }^{*} P<0.01$ vs. NC, $+P<0.05$, $++P<0.01$ vs. each stage of HCC. 


\subsection{Reciprocal Interactions with sTAMRs Levels and Their Ligands Levels in Patients with HCC, and in Other Liver Diseases}

In the three TAM-receptors, the plasma sMer and sTyro3 levels significantly correlated in HCC and other liver diseases; the correlation coefficients were $0.544^{*}\left({ }^{*} \mathrm{P}<0.05\right), 0.170$ (not significant; $\left.\mathrm{ns}\right), 0.551^{*}\left({ }^{*} \mathrm{P}<0.05\right), 0.619^{*}\left({ }^{*} \mathrm{P}<\right.$ $0.05), 0.564^{\star}\left({ }^{\star} \mathrm{P}<0.05\right)$ for HCC, FH, AH, CH, and LC patients, respectively.

Plasma Gas6 and sAxl levels in HCC cases were significantly correlated, and the correlation coefficient was $0.763^{* *}\left({ }^{* *} \mathrm{P}<0.01\right)$. Plasma levels of Gas6 and sAxl were correlated in the patients with liver diseases; the correlation coefficients were $-0.770(\mathrm{~ns}), 0.660^{\star}\left({ }^{\star} P<0.05\right), 0.408$ (not significant), $0.535^{\star}\left({ }^{\star} P<\right.$ 0.05 ) for $\mathrm{FH}, \mathrm{AH}, \mathrm{CH}$, and LC respectively. Plasma levels of Gas6 and sAxl in patients with FH showed a significantly negative correlation (Figure 3).

Plasma sMer and free PORS1 levels were significantly negatively correlated in HCC patients, and the correlation coefficient was $-0.574^{\star *}\left({ }^{* *} P<0.01\right)$. Plasma sMer and free PROS1 levels were also negatively correlated in patients with $\mathrm{FH}$, $\mathrm{AH}, \mathrm{CH}$, and $\mathrm{LC}$, and the correlation coefficients were $-0.365,-0.346,-0.270$, and $-0.634^{* *}\left({ }^{* *} P<0.01\right)$, respectively. A significant negative correlation was found only in LC patients between sMer and free PROS1 (Figure 4).

\subsection{The Changes of Ratios Three sTAMRs Levels of the HCC Patients/Three sTAMRs Levels of the NCs in the Progress of HCC}

The changes of the ratios of three sTAMRs of HCC/three sTAMRs of NCs in the progress of HCC cases are expressed in Figure 5(a).

The changes of sTyro3 continued high level from early stage of HCC. As for the sAxl levels, increase is remarkable from middle stage of HCC, and sMer

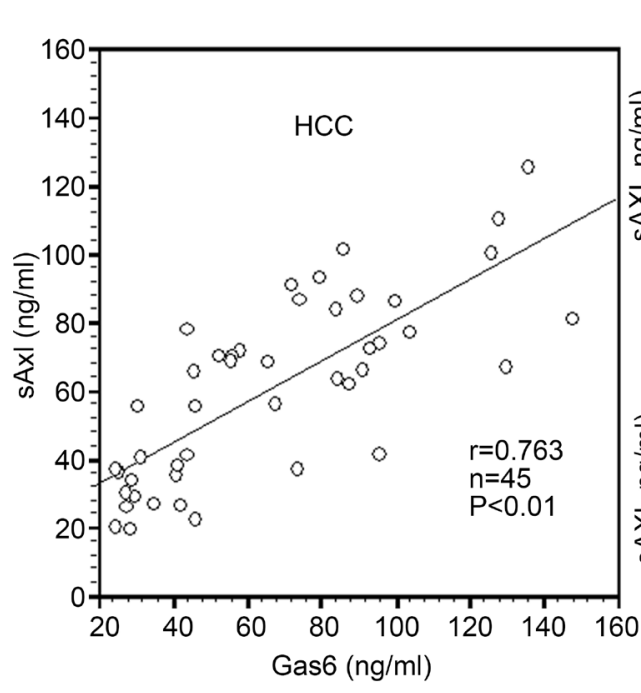

(a)

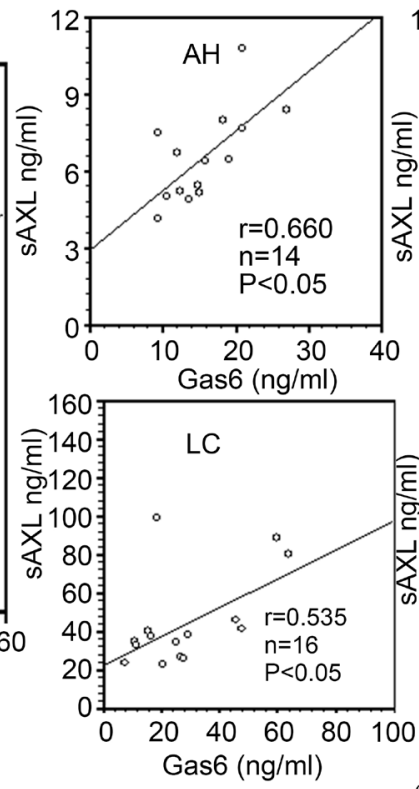

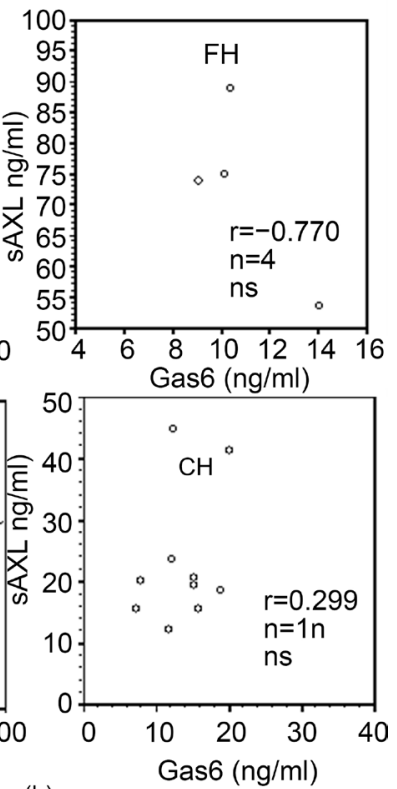

(b)

Figure 3. Correlation between plasma levels of sAxl and Gas6 in patients with HCC (a), and other liver diseases (b). 


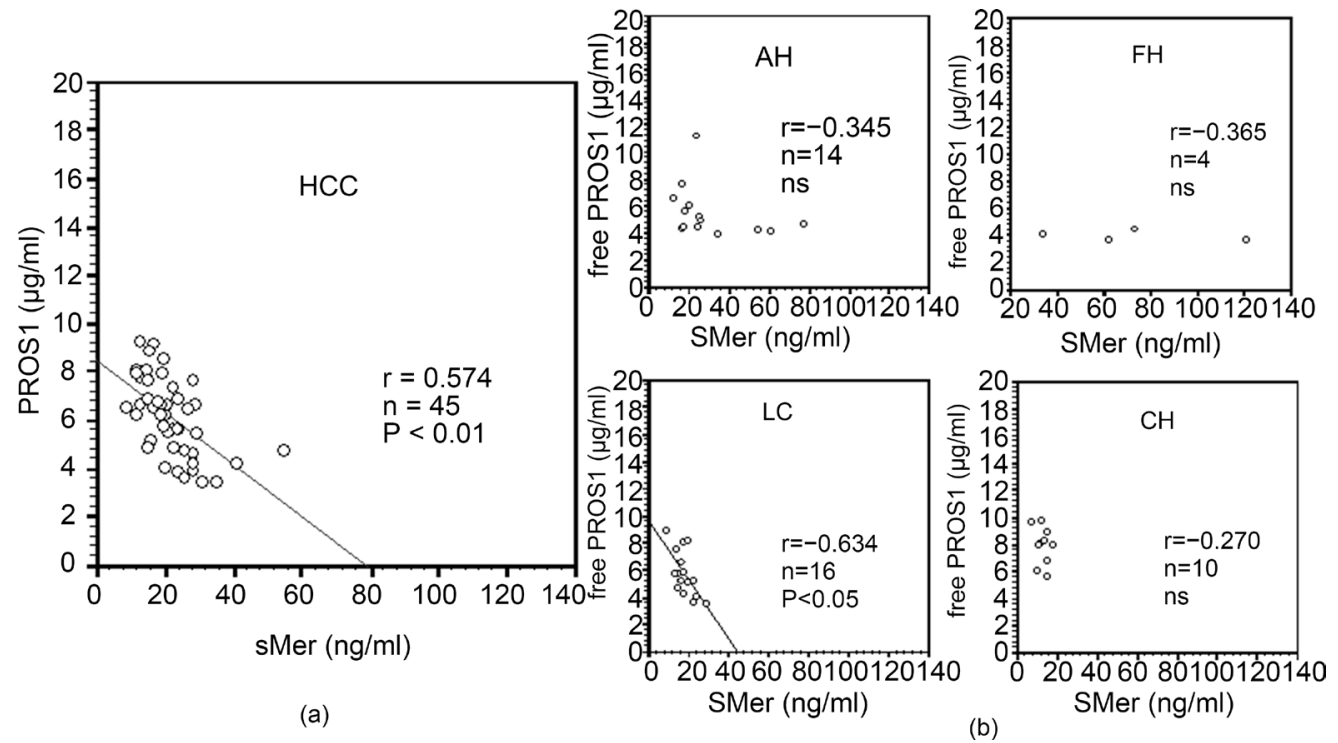

Figure 4. Correlation between plasma levels of sMer and free PROS1 in patients with HCC (a), and other liver diseases (b).

levels increased in late stage of HCC. Fluctuation of sTAMRs levels in the stage progression of HCC cases showed peaks in the order TAM (Figure 5(a)).

\subsection{The Levels and Correlations of sTAMRs and Their Ligands in the Three Macroscopic Tissue Types (Nodular, Diffuse, and Massive) of HCC}

The number of nodular, diffuse, and massive cases was 10,17 , and 18 , respectively.

Gas6 and three sTAMRs levels increased with the clinical stage development of the three HCC tissue types, and in tissue types with much fibrosis (massive or diffuse types). However, PROS1 decreased according to progress of HCC. (Figure 5(b)).

\subsection{The Ratios of Gas6/Total Three sTAMRs, and Total of Two sTAMRs (sMer and sTyro3)/Free PROS1 in HCC Cases, Other Liver Diseases (AH, CH, LC and FH ) Patients, and NCs}

Gas6/total three TAMRs ratio in the stage from I to IV of HCC, $\mathrm{FH}, \mathrm{AH}, \mathrm{CH}$, LC and NC were $0.60 \pm 0.08^{\star}, 0.57 \pm 0.10^{\star}, 0.71 \pm 0.21^{\star \star}, 0.80 \pm 0.28^{\star \star}, 0.08 \pm$ $0.05^{* *}, 0.2 \pm 0.05^{* *}, 0.37 \pm 0.14,0.41 \pm 0.17$, and $0.42 \pm 0.08$ respectively $\left({ }^{*} \mathrm{P}<\right.$ $\left.0.05,{ }^{* *} \mathrm{P}<0.01\right)$. The total sTyro3 and sMer/free PROS1 ratio in the stage from I to IV of HCC, $\mathrm{FH}, \mathrm{AH}, \mathrm{CH}, \mathrm{LC}$ and $\mathrm{NC}$ were $2.15 \pm 0.37^{\times 100 *}, 5.58 \pm$ $3.07^{\times 100 *}, 5.81 \pm 2.56^{\times 100 * \star}, 5.58 \pm 2.13^{\times 100 * *}, 42.5 \pm 37.2^{\times 100 *}, 7.56 \pm 5.4^{1 \times 100 *}, 3.06$ $\pm 2.29^{\times 100}, 4.70 \pm 2.44^{\times 100}$, and $1.62 \pm 0.32^{\times 100}$ espectively $\left({ }^{*} \mathrm{P}<0.05\right.$, ${ }^{*} \mathrm{P}<0.01$ vs $\mathrm{NC})$.

Both of Gas6/ total three sTAMRs, and total of two sTAMRs (sMer and sTyro3)/free PROS1 ratios in HCC patients increased than it of NCs ratios, and according to progress the stages, but ratio of the Gas6/total three sTAMRs in the other liver diseases (i.e. $\mathrm{AH}, \mathrm{CH}, \mathrm{LC}$, and $\mathrm{FH}$ ) patients lower than it of NCs. In 
contrast, ratios of the total of sMer and sTyro3/free PROS1 in the other liver diseases patients were higher than it of NCs ratio (Figure 5(c) Figure 5(d)).

\subsection{Correlation between Gas 6 Levels and Des- $\gamma$-Carboxy Gas 6 Levels in Patients with HCC}

The des- $\gamma$-carboxy Gas6 levels in HCC cases increased with the progression of HCC. Gas6 and des- $\gamma$-carboxy Gas6 levels were correlated $\left(\mathrm{r}=0.581^{\star},{ }^{\star} P<\right.$ $0.05)$. The des- $\gamma$-carboxy Gas6 levels significantly increased from HCC stage I IV (Figure 6(a) Figures 6(b)).

\subsection{Correlation Coefficients between Child-Pugh Scores and sTAMRs, and Their Ligands in Patients with HCC and Other Liver Diseases}

The correlation coefficients between Child-Pugh scores, and sAxl, sMer, sTyro3, Gas6, and free PROS1 levels in HCC patients were $0.317^{\star}, 0.351^{\star}, 0.373^{*}, 0.356^{*}$, and $-0.386^{\star}$, respectively $\left({ }^{\star} \mathrm{P}<0.05\right)$. Likewise, the correlation coefficient between Child-Pugh scores, and the levels of sTAMRs, in HCC patients was $0.449^{\star}$ $\left({ }^{*} \mathrm{P}<0.05\right)$.

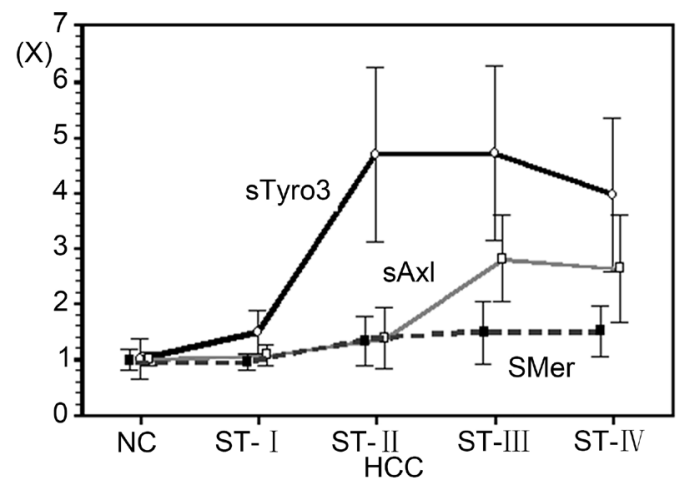

(a)

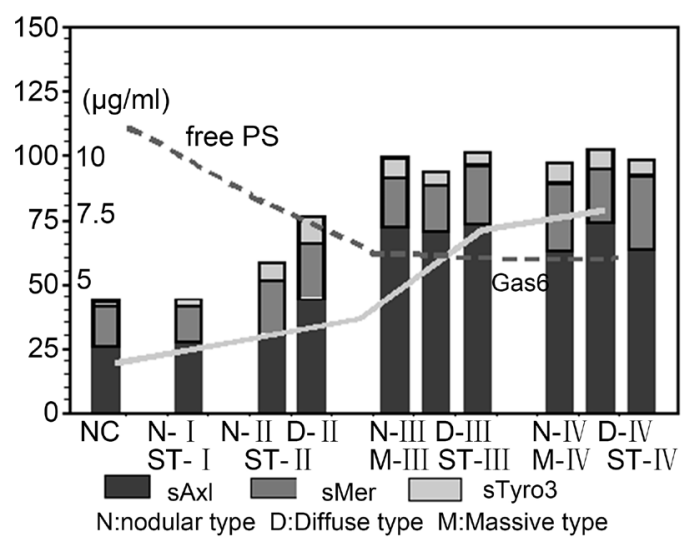

(d)

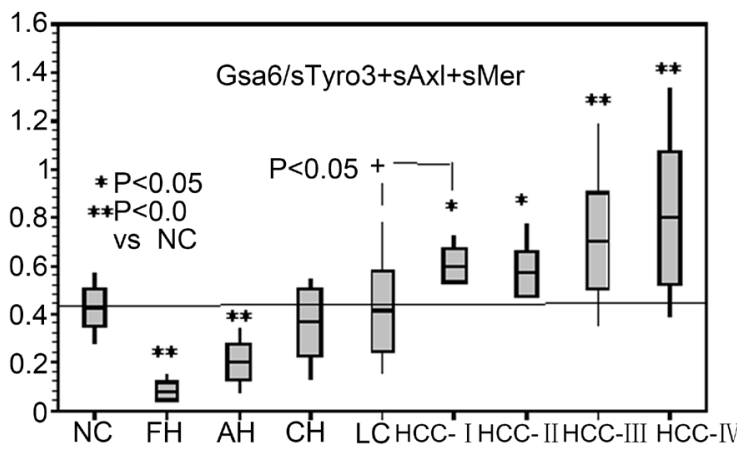

(c)

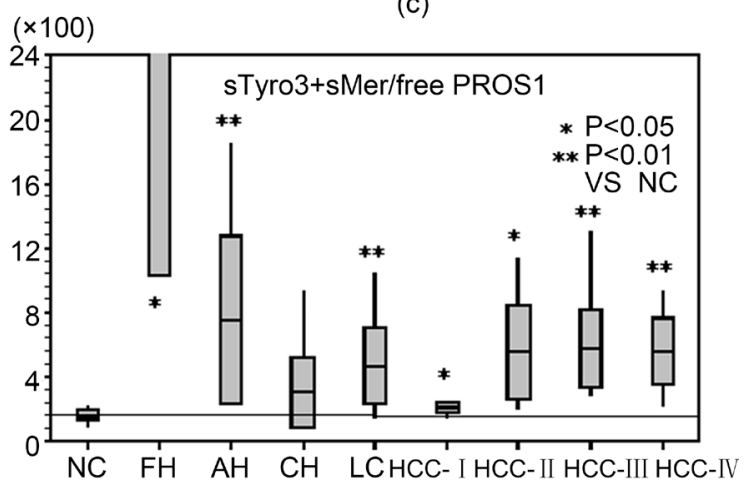

(d)

Figure 5. The changes of ratios three sTAMRs levels of the HCC patients/three sTAMRs levels of the NCs in the progress of HCC (a), the levels of sTAMRs and their ligands in the three macroscopic HCC tissue types (b), and the ratios of Gas6/total of three sTAMRs (c) and the total of two TAMRs (sMer and sTyro3)/free PROS1 in HCC patients, other liver diseases (AH, CH, LC and FH) patients, and NCs (d). Data are mean values, mean \pm standard deviation. 


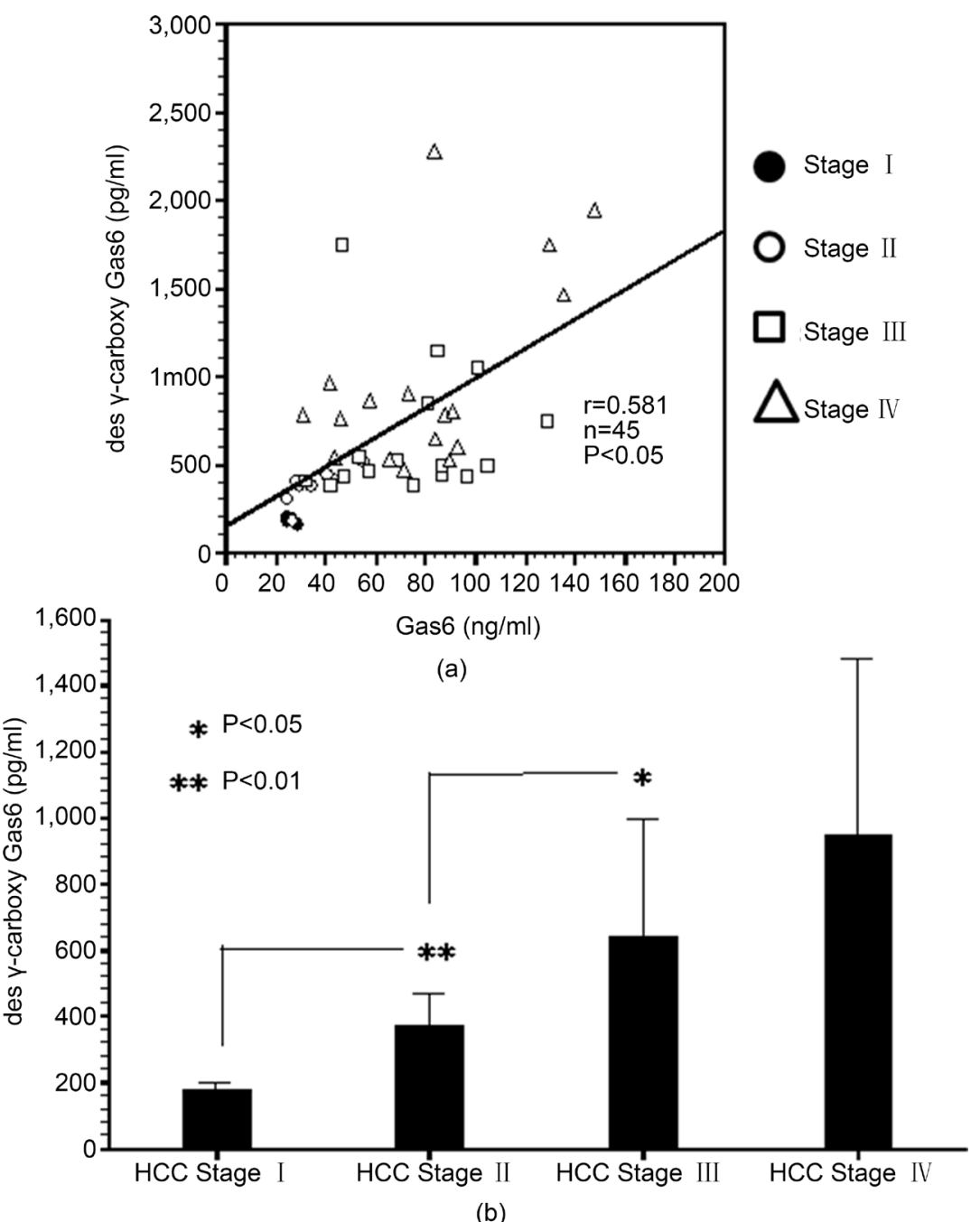

Figure 6. Correlation between Gas6 and des- $\gamma$-carboxy Gas6 in patients with HCC (a), and des- $\gamma$-carboxy Gas6 level in stage with HCC (b). Data are mean \pm standard deviation.

Conversely, the correlation between Child-Pugh scores, and sAxl, sMer, sTyro3, Gas6, and free PROS1 levels in patients of $\mathrm{FH}, \mathrm{AH}$, and $\mathrm{CH}$ showed no clear tendency.

\section{Discussion}

The Gas6/PROS1-TAM system regulates key features of cellular physiology and its modulation could lead to interesting therapeutic targets in thrombotic disease [17], such as sepsis [18], autoimmune disease [19] [20], atherosclerosis [21] and cancer [22] [23]. The differential activities of the TAM ligands Gas6 and PROS1 remain poorly understood.

When activated by Gas6, hemostasis is promoted by an activated platelet and tissue factor, and protein $\mathrm{S}$ has a TAM-independent inhibitory effect on hemostasis [5] [24].

Though Gas6 develops in many organs, the main site of synthesis for Gas6 is not the liver. Gas6 and TAMs are mainly found in Hepatic Stellate Cells (HSCs) 
and not in hepatocytes, and are mainly derived from activated HSCs [25]. HSCs associated with various immune-modulatory functions have been shown to induce Myeloid Derived Suppressor Cells (MDSC) from myeloid cells, and they plays an important role in liver carcinogenesis as key modulators of fibrosis and the tumor cell microenvironment [26] [27].

In recent studies, a hepatoprotective role for Gas6 was observed in several acute liver damage models, whereas its deficiency was associated with decreased liver fibrosis [28] [29] [30]. Furthermore, the Gas6 acts for hepatoprotection in the severe acute liver damage experiment [30] [31].

Fluctuation of three sTAMRs and their ligands in FH patients is remarkable increase of sTAMRs and consumption of their ligands, and Gas6 and sAxl in the same patients show negative relationship. This situation resembles PROS1, Gas6 and Axl deficiency.

PROS1 $^{-1-}$ mice have a lethal coagulopathy and vascular malformation, and this vascular malformation is most probably due to the impaired blood flow caused by thrombus formation, and this situation could speculate it to be due to insufficient Axl signaling. As a result, the signaling of these sTAMRS results in no reaction, and these clinical features are lethal coagulopathy, and disturbance of consciousness is to come from hepatic encephalopathy with severe inflammation [32] [33] [34].

In patients with $\mathrm{AH}, \mathrm{CH}, \mathrm{LC}$, and $\mathrm{FH}$, the Gas6/total three sTAMRs ratios were lower than NCs, and the total of two sTAMRs (sTyro3 and sMer)/free PROS1 ratios was higher than NCs. It was thought that these results expressed characteristics of the production organ of the Gas6 and PROS1.

As a result, the consumption of Gas6 with hepatoprotective function contributes to the prognosis in the hepatitis group of the acute phase ( $\mathrm{FH}$ and $\mathrm{AH}$ ).

On the other hand, Gas6 plasma level increases in parallel to liver fibrosis in chronic liver diseases (CH and LC) progression [35]. Liver fibrosis in the development of liver cirrhosis with persistent inflammation may lead to a favorable microenvironment for cancer development.

Overexpression of TAMRs was observed in HCC cases as well as other cancers. In three sTAMRS, the levels of sTyro3 continued high level from early stage of HCC.

Tyro3 is most abundantly expressed in the nervous system and many other tissues, and the action of Tyro3 can lead to cells transformation in vitro, and can promote malignancy by inducing proliferation [36]. Recently, the study by Chan, et al. revealed that the function of Tyro3 is essential, selective inhibitor of type 2 immunity [37] [38]. In HCC, both of the Gas6/total three sTAMRs and total sTyro3 and sMer/free PROS1 ratios increased, but, according to the development of HCC, these levels increased in Gas6 predominance in comparison with PROS1. The three sTANRs levels in HCC groups increased than NCs and increased according to the progression and metastasis. Tyro3 overexpression promotes cancer cell-survival by overcoming senescence.

As for the sAxl levels, the increase is remarkable from middle stage of HCC. 
The activation of Axl signaling by its ligand Gas6 leads to enhanced proliferation, survival, invasion, resistance against apoptosis, and metastasis of cancer cells. In HCC, in situ hybridization revealed up-regulation of Axl and a further study suggested that Axl acts downstream of the Hippo pathway to trigger cell invasion and metastasis [39] [40].

The sMer levels increased gradually in late stage of HCC. Mer can act in an anti-inflammatory manner being expressed primarily on anti-inflammatory $\mathrm{M} 2 \mathrm{c}$ macrophages, and cleavage of Mer occurs via ADAM17, which is also known as tumour necrosis factor- $\alpha$-converting enzyme (TACE) [7]. In the tumor, Mer contributes to tumor growth and metastasis through macrophage [3] [41] [42].

Furthermore, three sTAMRs and Gas6 levels in the three HCC macroscopic tissue types (degree of fibrosis of each tissue types became the order of massive $\geq$ diffuse $>$ nodular by the measurement of matrix metalloproteinases. data not shown.) increased in parallel with their fibrosis progression.

From these results, the difference between HCC patients and other hepatitis patients in Gas6/PROS1.TAM system is increase of plasma Gas6 levels which is higher than NCs range.

Recently Loges et al. [43] determined the role of macrophage-derived Gas6 in experimental solid tumor models. In their study, tumor-infiltrating macrophages display higher levels of Gas6 than their splenic counterparts.

This finding raises the possibility that factors predominant or enriched in the tumor microenvironment, including IL-10 and M-CSF, lead to Gas6 upregulation in tumor-associated macrophages. Tumor-associated macrophages, in turn, use upregulated Gas6 to engage TAMRs in tumor cells. There is suspected that the biosynthesis of Gas6 of these HCC in activated Hepatic Stellate Cells (HSCs) in the tumor cell microenvironment in hepatic fibrosis [26] [27] [29].

Furthermore, recent reports by Tso, et al. [44] and Lew, et al. [45] revealed the mechanisms of signaling mediated by Gas6 and PROS1 via interactions with three TAMs. According to their reports, sTAMs act as specific ligand antagonists. The phosphatidylserine (PtdSer) lipid vesicles, apoptotic cells, and enveloped viruses in local tissues significantly potentiate the ligand-induced activation of Mer and to a lesser extent Tyro3, but not Axl. For example, sTyro3 and sAxl act as effective ligand antagonists by blocking PROS1- and Gas6-induced by TAMs, respectively. sMer shows weak inhibitory activities toward both ligands. Gas6 lacking its PtdSer-binding Gla-domain (namely the des- $\gamma$-carboxy Gla or Gla-less domain) is significantly weakened as a Tyro3/Mer agonist and inert as an Axl agonist. In other words, Axl bound des- $\gamma$-carboxy Gas6 is dead as a ligand, and Mer and Tyro3 bound des- $\gamma$-carboxy Gas6 have partial kinase activation [44] [45]. The increase of the des- $\gamma$-carboxyGas6 level was found according to development of the stage of disease of HCC and a correlation was found between des- $\gamma$-carboxy Gas6 and Gas6 levels. Our finding that the sAxl level at stage 5 decreased in comparison with the sAxl at stage 3, but sMer, sTyro3 and the Gas6 levels continued to gradually increase with the progression of the disease, indicates that in advanced stages of HCC, Mer and Tyro3 plays a predomi- 
nant role and that Axl is dispensable [44] [45].

It was estimated that the same mechanism intervened between both of the increase of des- $\gamma$-carboxy Gas6 and des- $\gamma$-carboxy prothrombin in HCC patients [46].

Furthermore, Paolino M., et al. reported that plausible model for warfarin's anti-metastatic activity, in which warfarin mediates rejection of metastatic tumors by blocking the activation of TAM/Cbl-b inhibitory circuits in NK cells and succeeded in tumor metastasis inhibition [47] [48].

As well as these, increases of des $\gamma$-carboxy-prothrombin and des $\gamma$-carboxy Gas6, and urinary $\gamma$-carboxyglutamic acid in HCC patients suggests presence of the acceleration of vitamin K metabolism in HCC tissues [49] [50].

For example, as a result of our measurement, studies of the vitamin $\mathrm{K}$ metabolism antagonists of TAM ligands, and TAM system may be performed. TAM signaling for HCC therapy shows different strategies for targeted TAM inactivation and the expected anti-cancer benefits of such therapies by affecting the tumor, or indirectly, via activation of the immune system. In future, many further studies are expected.

\section{Conflict of Interest}

The authors decade that they have no conflict of interest.

\section{Acknowledgements}

We thank Dr. Kesuke Watanabe of Eisai KK. and Dr Takusi Kawamura of Einos KK for support and advice.

\section{References}

[1] Lemke, G. (2013) Biology of TAM Receptors. Biology of the TAM Receptors. Cold Spring Harbor Perspectives in Biology, 5, Article ID: a009076. https://doi.org/10.1101/cshperspect.a009076

[2] Balogh, I., Hafizi, S., Stenhoff, J., Hansson, K. and Dahlbäck, B. (2005) Analysis of Gas6 in Human Platelets and Plasma. Arteriosclerosis, Thrombosis, and Vascular Biology, 25, 1280-1286. https://doi.org/10.1161/01.ATV.0000163845.07146.48

[3] Linger, R.M., Keating, A.K., Earp, H.S. and Graham, D.K. (2008) TAM Receptor Tyrosine Kinases: Biologic Functions, Signaling, and Potential Therapeutic Targeting in Human Cancer. Advances in Cancer Research, 100, 35-83. https://doi.org/10.1016/S0065-230X(08)00002-X

[4] Hafizi, S. and Dahlbäck, B. (2006) Gas6 and Protein S. Vitamin K-Dependent Ligands for the Axl Receptor Tyrosine Kinase Subfamily. The FEBS Journal, 273, 5231-5244. https://doi.org/10.1111/j.1742-4658.2006.05529.x

[5] Ekman, C., Stenhoff, J. and Dahlbäck, B. (2010) Gas6 Is Complex to the Soluble Tyrosine Kinase Receptor Axl in Human Blood. Journal of Thrombosis and Haemostasis, 8, 838-844. https://doi.org/10.1111/j.1538-7836.2010.03752.x

[6] Budagian, V., Bulanova, E., Orinska, Z., Duitman, E., Brandt, K., Ludwig, A., et al. (2005) Soluble Axl Is Generated by ADAM10-Dependent Cleavage and Associates with Gas6 in Mouse Serum. Journal of Molecular Cell Biology, 25, 9324-9339. https://doi.org/10.1128/MCB.25.21.9324-9339.2005 
[7] Black, R.-A., Rauch, C.T., Kozlosky, C.J., Peschon, J.-J., Slack, J.-L., Wolfson, M.-F., et al. (1997) A Metalloproteinase Disintegrin That Releases Tumor-Necrosis FactorAlpfa from Cells. Nature, 385, 729-733. https://doi.org/10.1038/385729a0

[8] Tsou, A.P., Wu, K.M., Tsen, T.Y., Chi, C.W., Chiu, J.H., Lui, W.Y., et al. (1998) Parallel Hybridization Analysis of Multiple Protein Kinase Genes: Identification of Gene Expression Patterns Characteristic of Human Hepatocellular Carcinoma. Genomics, 50, 331-340. https://doi.org/10.1006/geno.1998.5338

[9] Xu, M.Z., Chan, S.W., Liu, A.M., Wong, K.F., Fan, S.T., Chen, J., et al. (2011) AXL Receptzor Kinase Is a Mediator of YAP-Dependent Oncogenic Functions in Hepatocellular Carcinoma. Oncogene, 30, 1229-1240.

https://doi.org/10.1038/onc.2010.504

[10] Reichl, P., Fang, M., Starlinger, P., Staufer, K., Nenutil, R., Muller, P., et al. (2015) Multicenter Analysis of Soluble Axl Reveals Diagnostic Value for Very Early Stage Hepatocellular Carcinoma. International Journal of Cancer, 137, 385-394. https://doi.org/10.1002/ijc.29394

[11] Duan, Y., Wong, W., Chua, S.C., Wee, H.L., Lim, S.G., Chua, B.T., et al. (2016) Overexpression of TYRO3 and Its Implications on Hepatocellular Carcinoma Progression. International Journal of Oncology, 48, 358-366.

[12] Liver Cancer Study Group of Japan (2000) The General Rules for the Clinical and Pathological Study of Primary Liver Cancer. 4th Edition, Kanehara, Tokyo. (In Japanese)

[13] Kudo, M., Izumi, N., Kokudo, N., Matsui, O., Sakamoto, M., Nakashima, O., et al. (2011) Management of Hepatocellular Carcinoma in Japan: Consensus-Based Clinical Practice Guidelines Proposed by the Japan Society of Hepatology (JSH) 2010 Updated Version. Digestive Diseases, 29, 339-364. https://doi.org/10.1159/000327577

[14] Enggel, H. (1901) Üeber das primare carcinoma der leber. Beitr. Z. Path. Anat. U.Z. Allg. Path., 30, 506-604. (In Germany)

[15] Pugh, R.N., Murray-Lyon, I.M., Dawson, J.L., Pietroni, M.C. and Williams, R. (1973) Transection of the Oesophagus for Bleeding Oesophageal Varices. British Journal of Surgery, 60, 646-649. https://doi.org/10.1002/bjs.1800600817

[16] Fujiwara, K., Mochida, S., Matsui, A., Nakayama, N., Nagoshi, S., Toda, G., et al. (2008) Fulminant Hepatitis and Late Onset Hepatic Failure in Japan. Hepatology Research, 38, 646-657. https://doi.org/10.1111/j.1872-034X.2008.00322.x

[17] Angelillo-Scherrer, A., Burnier, L., Flores, N., Savi, P., DeMol, M., Schaeffer, P., et al. (2005) Role of Gas6 Receptors in Platelet Signaling during Thrombus Stabilization and Implications for Antithrombotic Therapy. Journal of Clinical Investigation, 115, 237-246. https://doi.org/10.1172/JCI22079

[18] Ekman, C., Linder, A., Akesson, P. and Dahlbäck, B. (2010) Plasma Concentrations of Gas6 (Growth Arrest Specific Protein 6) and Its Soluble Tyrosine Kinase Receptor sAxl In sepsis and Systemic Inflammatory Response Syndromes. Critical Care, 14, R158. https://doi.org/10.1186/cc9233

[19] Ekman, C., Jönsen, A., Sturfelt, G., Bengtsson, A.A. and Dahlbäck, B. (2011) Plasma Concentrations of Gas6 and sAxl Correlate with Disease Activity in Systemic Lupus Erythematosus. Rheumatology, 50, 1064-1069. https://doi.org/10.1093/rheumatology/keq459

[20] Wu, J., Ekman, C., Jönsen, A., Sturfelt, G., Bengtsson, A.A., Gottsäter, A., et al. (2011) Increased Plasma Levels of the Soluble Mer Tyrosine Kinase Receptor in Systemic Lupus Erythematosus Relate to Disease Activity and Nephritis. Arthritis Research \& Therapy, 13, R62. https://doi.org/10.1186/ar3316 
[21] Ekman, C., Site, D.F., Gottsäter, A., Lindblad, B. and Dahlbäck, B. (2010) Plasma Concentrations of Growth Arrest Specific Protein 6 and the Soluble Form of Its Tyrosine Kinase Receptor Axl as Markers of Large Abdominal Aortic Aneurysms. Clinical Biochemistry, 43, 110-114. https://doi.org/10.1016/j.clinbiochem.2009.07.025

[22] Linger, R.M., Keating, A.K., Earp, H.S. and Graham, D.K. (2008) TAM Receptor Tyrosine Kinases: Biologic Functions, Signaling, and Potential Therapeutic Targeting in Human Cancer. Advances in Cancer Research, 100, 35-83. https://doi.org/10.1016/S0065-230X(08)00002-X

[23] Sun, W., Fujimoto, J. and Tamaya, T. (2004) Coexpression of Gas6/Axl in Human Ovarian Cancers. Oncology, 66, 450-457. https://doi.org/10.1159/000079499

[24] Robins, R.S., Lemarié, C.A., Laurance, S., Aghourian, M.N., Wu, J. and Biostein, M.D. (2013) Vacular Gas6 Contributes to Thrombogenesis and Promotes Tissue Factor Up-Regulation after Vessel Injury in Mice. Blood, 121, 692-699. https://doi.org/10.1182/blood-2012-05-433730

[25] Couchie, D., Lafdil, F., Martin-Garcia, N., Laperche, Y., Zafrani, E.S. and Maviet, P. (2005) Expression and Role of Gas6 Protein and Its Receptor Axl in Hepatic Regeneration from Cells in the Rat. Gastroenterology, 29, 1633-1642. https://doi.org/10.1053/j.gastro.2005.08.004

[26] Garcia, M.G., Bayo, J., Bolontrade, M.F., Sganga, L., Maivicini, M., Alaniz, L., et al. (2011) Hepatocellular Carcinoma Cells and Their Fibrotic Microenvironment Modulate Bone Marrow-Derived Mesenchymal Stromal Cell Migration in Vitro and in Vivo. Molecular Pharmacology, 8, 1538-1548. https://doi.org/10.1021/mp200137c

[27] Coulouarn, C., Cortu, A., Glaise, D., Guenon, I., Thorgerisson, S.S. and Clement, B. (2012) Hepatocyte-Stellate Cell Cross-Talk in the Liver Engenders a Permissive Inflammatory Microenvironment That Drives Progression in Hepatocellular Carcinoma. Cancer Research, 72, 2533-2542. https://doi.org/10.1158/0008-5472.CAN-11-3317

[28] Fourcot, A., Couchie, D., Chobert, M.-N., Zafrani, E.-S., Mavier, P., Laperche, Y., et al. (2011) Gas6 Deficiency Prevent Liver Inflammation, Steatohepatitis, and Fibrosis in Mice. American Journal of Physiology, 300, 1043-1053.

[29] Lafdil, F., Chobert, M.N., Couchie, D., Broillet, A., Zafrani, E.S., Mavier, P., et al. (2006) Induction of Gas6 Protein in CCL4-Induced Rat Liver and Antiapoptotic Effect on Hepatic Stellate Cells. Hepatology, 44, 228-239.

https://doi.org/10.1002/hep.21237

[30] Lafdil, F., Chobert, M.N., Deveaux, V., Zafrani, E.S., Mavier, P., Nakano, T., Laperche, Y. and Brouillet, A. (2009) Growth Arrest-Specific Protein 6 Deficiency Impairs Liver Tissue Repair after Acute Toxic Hepatitis Mice. Journal of Hepatolo$g y$, 51, 55-66. https://doi.org/10.1016/j.jhep.2009.02.030

[31] Liacuna, L., Bárcena, C., Bellido-Martin, L., Femández, L., Stefanovic, M., Mari, M., et al. (2010) Growth Arrest-Specific Protein 6 Is Hepatoprotective against Ischemia/Reperfusion Injury. Hepatology, 52, 1371-1379. https://doi.org/10.1002/hep.23833

[32] TenKate, M.K. and van der Meer, J. (2008) Protein S Deficiency: A Clinical Perspective. Hemophilia, 14, 1222-1228.

[33] Lu, Q. and Lemke, G. (2001) Homeostatic Regulation of the Immune System by Receptor Tryosine Kinases of the TYRO3 Family. Science, 293, 306-311. https://doi.org/10.1126/science.1061663

[34] Burstyn-Cohen, T., Heeb, M.J. and Lemke, G. (2009) Lack of Protein S in Mice 
Causes Embryonic Lethal Coagulopathy and Vascular Dysgenesis. Journal of Clinical Investigation, 119, 2942-2953. https://doi.org/10.1172/JCI39325

[35] Bárcena, C., Stefanovic, M., Tutusaus, A., Joannas, L., García-Ruiz, M.A., et al. (2015) Gas6/Axl Pathway Is Activated in Chronic Liver Disease and Its Targeting Reduces Fibrosis via Hepatic Stellate Cell in Activation. Journal of Hepatology, 63, 670-678. https://doi.org/10.1016/j.jhep.2015.04.013

[36] Lai, C., Gore, M. and Lemke, G. (1994) Structure, Expression, and Activity of TYRO3, Aneural Adhesion-Related Receptor Tyrosine Kinase. Oncogene, 9, 25672578.

[37] Chan, P.Y., Silva, E.A.C., DeKouchkovsky, D., Joannas, L.D., Hao, L., Hu, D., Huntsman, S., Eng, C., Licona-Limon, P., Weinstein, J.S., et al. (2016) The TAM Family Receptor Tyrosine Kinases TYRO3 Is a Negative Regulator of Type 2 Immunity. Science, 352, 99-103. https://doi.org/10.1126/science.aaf1358

[38] Budhu, A., Forgues, M., Ye, Q.H., Jia, H.L., He, P., Zanetti, K.A., et al. (2005) Prediction of Veous Metastasis, Recurrence, and Prognosis in Hepatocellular Carcinoma Based on a Unique Immune Response Signature of the Liver Microenvironment. Cancer Cell, 10, 99-111. https://doi.org/10.1016/j.ccr.2006.06.016

[39] He, L., Zhang, J., Jin, C., Zhao, Y., Yang, G. and Jia, L. (2010) Differential Expression of Axl in Hepatocellular Carcinoma and Correlation with Tumor Lymphatic Metastasis. Molecular Carcinogenesis, 49, 882-891. https://doi.org/10.1002/mc.20664

[40] Xu, M.Z., Chan, S.W., Liu, A.M., Wong, K.F., Fan, S.T., Chen, J., et al. (2011) AXL Receptor Kinase Is a Mediator of YAP-Dependent Oncogenic Functions in Hepatocellular Carcinoma. Oncogene, 30, 1229-1240. https://doi.org/10.1038/onc.2010.504

[41] Linger, R.M., Keating, A.K., Earp, H.S. and Graham, D.K. (2010) Taking aim at Mer and Axl Receptor Tyrosine Kinases as Novel Therapeutic Targets in Solid Tumors. Expert Opinion on Therapeutic Targets, 14, 1073-1090. https://doi.org/10.1517/14728222.2010.515980

[42] Cook, R.S., Jacobsen, K.M., Wofford, A.M., DeRyckere, D., Stanford, J., Prieto, A.L., et al. (2013) Mer TK Inhibition in Tumor Leukocytes Decreases Tumor Growth and Metastasis. Journal of Clinical Investigationig, 123, 3231-3242. https://doi.org/10.1172/JCI67655

[43] Loges, L., Schmidt, T., Tjwa, M., Geyte, K., Lievens, E., Vanhoutte, D., et al. (2010) Malignant Cells Fuel Tumor Growth by Educating Infiltrating Leukocytes to Produce the Mitogen Gas6. Blood, 115, 2264-2273. https://doi.org/10.1182/blood-2009-06-228684

[44] Tso, W.-I., Nguyen, K.-Q.N., Calarse, D.A., Garforth, S.J., Antes, A.L., Smirnov, S.V., et al. (2014) Receptor Tyrosine Kinases, TYRO3, AXL and MER, Demonstrate Distinct Patterns and Complex Regulation of Ligand-Induced Activation. Journal of Biological Chemistry, 289, 2570-2563. https://doi.org/10.1074/jbc.m114.569020

[45] Lew, E.D., Oh, J., Burrola, P.G., Lax, I., Zagórska, A., Través, P.G., et al. (2014) Differential TAM Receptor-Ligand-Phospholipid Interactions Delimit Differential TAM Bioactivities. Elife, 29, 3.

[46] Uehara, S., Gotoh, K., Handa, H., Tomita, H. and Senshuu, M. (2005) Distribution of the Heterogeneity of Des- $\gamma$-Carboxyprothrombin in Patients with Hepatocellular Carcinoma. Journal of Gastroenterology and Hepatology, 20, 1545-1552. https://doi.org/10.1111/j.1440-1746.2005.03899.x

[47] Paolino, M., Choidas, A., Wallner, S., Pranjic, B., Uribesalgo, I., Loeser, S., Jamieson, A.M., Langdon, W.Y., et al. (2014) The E3 Ligase Cbl-b and TAM Receptors 
Regulate Cancer Metastasis via Natural Killer Cells. Nature, 507, 508-512. https://doi.org/10.1038/nature12998

[48] Paolino, M. and Penninger, J. (2016) The Role of TAM Family Receptors in Immune Cell Function: Implications for Cancer Therapy. Cancers, 8, 97. https://doi.org/10.3390/cancers8100097

[49] Goto, K., Kato, S., Sumiya, S., Uehara, S., Hirayama, A., Sakamoto, W., Tokumitsu, Y. and Takada, M. (1994) Urinary Levels of $\gamma$-Carboxyglutamic Acid and Its Clinical Significance. Biological and Pharmaceutical Bulletin, 17, 142-145. https://doi.org/10.1248/bpb.17.142

[50] Uehara, S., Gotoh, K., Handa, H. and Maki, Y. (2013) Plasma Levels of Growth Arrest Specific Protein (Gas6) and the Solublue Form of Its Tyrosine Kinase Receptor Axl(sAxl) in Patients with Hepatocellular Carcinoma. Journal of Cancer Therapy, 4, 632-639. https://doi.org/10.4236/jct.2013.42079

Submit or recommend next manuscript to SCIRP and we will provide best service for you:

Accepting pre-submission inquiries through Email, Facebook, LinkedIn, Twitter, etc. A wide selection of journals (inclusive of 9 subjects, more than 200 journals)

Providing 24-hour high-quality service

User-friendly online submission system

Fair and swift peer-review system

Efficient typesetting and proofreading procedure

Display of the result of downloads and visits, as well as the number of cited articles

Maximum dissemination of your research work

Submit your manuscript at: http://papersubmission.scirp.org/

Or contact jct@scirp.org 